\title{
Suomen maataloudella mahdollisuuksia globaalimuutosten myllerryksessä
}

Erikoistutkija, TkT Heikki Lehtonen, Maa- ja elintarviketalouden tutkimuskeskus, Taloustutkimus

\section{Tiivistelmä}

Suomessa tuottavuuden on ennakoitu kasvavan jatkossa jopa kymmeniä prosentteja vuoteen 2050 mennessä suotuisammaksi muuttuvan ilmaston ja erityisesti pitenevän kasvukauden ansiosta. Tämä tarjoaa haasteita ja mahdollisuuksia maataloudelle. Tässä tutkimuksessa on arvioitu maatalouden sopeutumista ilmastonmuutokseen käytetty pitkän aikavälin sopeutumiseen räätälöityä osittaistasapainomallia. Siinä maataloustuotannon rakenne alueittain voi ajan mittaan muuttua merkittävästi, mikäli muutosta suosivat tuottavuus- ja hintasuhdemuutokset vaikuttavat riittävän pitkään. Tuottojen kasvava vaihtelu ja viljelijöiden riskinkarttaminen on otettu huomioon eksplisiittisesti osana maataloustuotemarkkinoita simuloivaa epälineaarista optimointimallia. Satotason nousun mahdollistamaa viljelyn muutosta alueittain arvioitiin käyttäen monia erilaisia hintasuhdeskenaarioita. Tuloksina saatiin maatalouden keskeiset riippuvuussuhteet huomioivat ennusteet kasvien viljelylaajuuksista Suomessa alueittain. Tuloksiin vaikuttavat myös paitsi valitut hintasuhdeskenaariot ja tuottavuusoletukset, myös oletukset elintarvikkeiden kysynnästä ja kysynnän hintajoustoisti. Näitä epävarmuuksia voidaan käsitellä tehdyn mallintamisen avulla ja arvioida, millä tuotantosuunnilla ja kasveilla olisi eniten menestymisen mahdollisuuksia ja merkitystä Suomen maataloudelle eri markkinaskenaarioissa.

Satoisammat ja pitenevän kasvukauden hyödyntävät kasvilajikkeet sekä markkinahintojen äärevöityneet muutokset tarjoavat viljelijöille mahdollisuuden riskinottoon ja sitä kautta hyviin tuloihin. Tulosten mukaan viljan vienti tulisi muutaman vuosikymmenen päästä painottumaan leipäviljan vientiin joka kasvaisi nykyistä rehuviljan vientiä suuremmaksi. Samoin maitotuotteiden vienti kasvaisi merkittävästi. Maataloustulo kasvaisi suhteellisesti vähemmän kuin satotaso.

Satotason nousu johtaa ensi vaiheessa vahvistuvaan alueelliseen erikoistumiseen tuotannossa, jossa ollaan jo ennestään vahvoja vuosikymmeninä niiden tuotannon kasvuun ensin Etelä-Suomessa, ja toisaalta karjatalouden samanaikaiseen voimistumiseen maan keski- ja pohjoisosissa. Syysmuotoiset kasvit ja öljykasvit yleistyvät pohjoisempana vasta myöhemmin ja sillä edellytyksellä, että tuottavuuden kasvu todella johtaa yksikkökustannusten selvään alenemiseen. Kustannusten olennainen aleneminen ei ole lainkaan itsestään selvää, koska on perusteita odottaa mm. energian ja lannoitteiden hintojen pysyvän korkeina ja heiluvan vielä maataloustuotteiden hintojakin enemmän. Viljelyn monipuolistuminen riippuu myös viljelijöiden riskinsietokyvystä ja riskinottohalukkuudesta.

Tuotannon olennainen lisääntyminen on Suomessa tuskin vielä pariin vuosikymmeneen taloudellisesti kannattavaa ilman kansallisia tuotanto- tai investointitukia. Tuen tarve voi vähentyä, jos tuottavuus kasvaa Suomessa nopeammin kuin muualla Euroopassa keskimäärin. Tuottavuuden nopeaa kasvua odotetaan kuitenkin myös mm. Tanskassa ja Pohjois-Saksassa. Korkeampi satotaso antaisi Suomessa mahdollisuuden vähentää rehun korjuukustannuksia erityisesti siellä, missä peltojen tilusrakenne on hajanainen. Kilpailuasetelman kääntyminen Suomen edessä edellyttää myös vahvaa rakennemuutosta ja tuotannon keskittämistä suotuisimmille alueille.

Avainsanat: ilmastonmuutos, Suomen maatalous, satopotentiaali, luonnonhaitta, alueellinen tuotantorakenne, riskien sieto 


\section{Johdanto}

Ilmastonmuutoksen odotetaan vaikeuttavan maanviljelyä suuressa osassa maailmaa, mutta parantavan monien kasvien viljelyolosuhteita Pohjois-Euroopassa (IPCC 2007, Jylhä et. al. 2004). Satopotentiaalin odotetaan kasvavan merkittävästi myös Suomessa kasvukauden lämpösumman ja sateisuuden kasvaessa. Samalla kasvavat tosin myös sääolosuhteiden ja satotason vaihtelut ja satoa uhkaavat haitat kuten kasvitaudit ja tuholaiset lisääntyvät. Muutokset vaikuttavat todennäköisesti hyvin eri tavalla eri kasveille ja tuotannonaloille.

MTT:n vetämässä Ilmastonmuutokseen sopeutuminen maa- ja elintarviketaloudessa -hankkeessa ${ }^{1}$ (ILMASOPU) tutkitaan, kuinka nopeasti nykyisten viljelykasvien viljelyalueet voivat laajentua ja miten aivan uudet tai meillä vähän viljellyt kasvit yleistyvät. Lisäksi selvitettiin, paljonko eri viljelykasvien sadot muuttuvat, kun kasvukausi pitenee. Tulosten mukaan nykyiset viljalajikkeet eivät hyötyisi ilmastonmuutosmallien ennustamista kasvukauden pidentymisistä. Hyödynnettävissä oleva kasvukauden pidennys osuisi kevääseen, ei syksyyn, joka lämpenee ja pitenee merkittävästi. Käyttökelpoinen ja sadon rakentumisen kannalta kriittinen sademäärä voi jopa pienentyä kuivien kesien ja rankkasateiden lisääntymisen vuoksi. Kasvukauden sadanta per potentiaalinen biomassa vähenee oleellisesti vaikka sademäärä sinällään kasvaisikin. Syyskylvöiset kasvit pystyisivät hyödyntämään paremmin aikaistuvan kasvukauden. Niiden laajamittainen viljely edellyttää kuitenkin ensin siirtymistä pysyvästi leutotalviseen ilmastoon talvehtimisongelmien vuoksi (Peltonen-Sainio et. al. 2009).

Teoreettinen kasvukauden pidentymisestä johtuva satopotentiaalin kasvu on kuitenkin tuntuva, jos uhat voitetaan. Pitkään kasvukauteen sopeutetuilla viljakasveilla jyväsadon on mahdollista nousta parhaassa tapauksissa jopa 7-8 tonniin vuoteen 2085 mennessä. Rypsillä ja rapsilla siemensatopotentiaali kasvaisi 3500 - 4300 kg /ha vuoteen 2085. Öljykasvien ja syysviljoja voidaan jo parin vuosikymmenen jälkeen viljellä satoja kilometrejä nykyistä pohjoisempana. Rapsin, herneen ja härkäpavun tuotannosta tulee silloin mahdollista suuressa osassa Suomea (Peltonen-Sainio et. al. 2009). Vuosisadan jälkipuoliskolla kokonaan uudet syysmuotoiset kasvit sekä valkuaiskasvit tulevat menestymään jopa Oulun korkeudella. Lajikkeiston tulisi kuitenkin vaihtua reippaalla tahdilla jo vuoteen 2025 mennessä. Teoreettisen potentiaalin saavuttaminen edellyttää myös haasteelliseksi muuttuvan kasvinsuojelun onnistumista kohtuukustannuksin. Nykyiset kasvitaudit tulevat hankalammiksi ja tulokaslajit vaativat uutta otetta kasvinsuojeluun.

Arvioitaessa ilmastonmuutoksen vaikutuksia Suomen maatalouteen huomio kiinnittyy kolmeen pääseikkaan: (1) Kasvuolosuhteiden muutosten vaikutus satotasoon ja viljelymahdollisuuksiin Suomessa ja sen eri alueilla; (2) Ilmastonmuutoksesta seuraava globaali tuottavuuden ja kysynnän kehitys sekä maatalouden panosten ja tuotosten hintasuhteet; (3) Satojen ja hintojen vaihteluiden voimistuminen.

Viimeksi mainittu seikka tarkoittaa sitä, että samalla kun sääolosuhteet Suomessa äärevöityvät, ilmastonmuutos voi johtaa myös globaalien elintarvikemarkkinoiden kasvaviin heilahteluihin. Elintason nousu tekee ruuan kysynnän joustamattomaksi hintamuutoksille, mistä seuraa aiempaa suurempia hintavaihteluja satovuosien vaihdellessa. OECD:n arvion mukaan voimakas hintojen heilahtelu ja kasvaneet taloudelliset riskit maataloudessa ovat suurimpia esteitä tavoiteltaessa pysyvää ruokaturvallisuutta.

\footnotetext{
${ }^{1}$ www.mtt.fi/tutkimusohjelmat ; http://mmm.multiedition.fi/mtt/eNewsletter3/2008/marraskuu/sivu4.php ; $\underline{\text { www.mtt.fi }}=>$ ajankohtaista $=>$ tiedotteet $=>$ tiedote 16.3. 2009
} 
Ilmastonmuutos vaikuttaa maataloudessa vahvasti jo nyt, mutta ei vielä koko painollaan. 2-3 viime vuoden aikana on saatu esimakua ilmastonmuutoksen aiheuttamasta myllerryksestä kasvavilla globaaleilla elintarvikemarkkinoille. Vuosien 2006-2009 aikana on koettu aiempaan verrattuna rajuja maataloustuotteiden ja maatalouden tuotantopanosten hintavaihteluita. Katovuodet suurissa viljantuottajamaissa ovat olleet tärkeä osatekijä maataloustuotteiden hintojen nousuun. Elintarvikkeiden kysynnän pitkään jatkunut kasvu sekä tuotantopanosten hintojen nousu ja lasku 2006-2009 on johtunut pääosin voimakkaasta talouskasvun vaihtelusta. Voimistuneet hintavaihtelut kytkeytyvät paitsi maatalouden sisäiseen kehitykseen ja satojen vaihteluun eri puolilla maailmaa, myös vahvasti taloudellisiin suhdanteisiin ja sosioekonomisiin kriiseihin. Näitä kaikkia on luvassa jatkossa sitä enemmän mitä voimakkaammin ilmasto muuttuu.

Ilmastonmuutos voi johtaa paitsi maataloustuotteiden hintojen, myös panoshintojen pysyvään nousuun. Tähän suuntaan vaikuttavat energiaverot ja kasvihuonekaasuja vähentävät politiikkatoimet, jotka uhkaavat tehdä energiasta ja lannoitteista pysyvästi kalliita. Keskeinen kysymys kuuluukin, pystyykö paljon energiaa, lannoitteita ja kalliita koneita käyttävä eurooppalainen ja suomalainen maatalous vastaamaan maataloustuotteiden hintojen nousuun. Lisäksi maataloustukien maksuperusteita on EU:ssa muutettu siten että tuet eivät kannusta tuottamaan, mikä on tullut ilmi erityisesti viime vuosina kun maatalouden tuotantopanokset ovat nopeasti kallistuneet ja ansiotaso muissa ammateissa on merkittävästi parantunut.

Seuraavassa arvioidaan Suomen maatalouden mahdollisuuksia ilmastonmuutokseen sopeutumisessa ja vaikutuksia tuotantoon koko maassa ja osin alueittain. Tehtyä työtä tulee pitää enemmän lähtölaukauksena tarkemmalle jatkotyölle kuin valmiina työnä tutkittaessa maatalouden sopeutumista ilmastonmuutoksen laaja-alaisiin ilmiöihin.

\section{Aineisto ja menetelmät}

Viimeisimmän kirjallisuuden pohjalta muodostettiin näkemys maatalousmarkkinoiden muutosmekanismeista ilmastonmuutoksessa. Keskeisiä tekijöitä ovat lihan ja rehuviljan kysyntä, hintojen kytkeytyminen energian hintaan ja kansainvälisiin suhdanteisiin sekä suhde lihan ja maitotuotteiden hintoihin. Kotieläintuotteissa globaali- ja EU:n sisäinen kilpailu kiristyy kansainvälisen kaupan laajentuessa ja mm. EU:n maitokiintiöistä luovuttaessa.

Tutkimusmenetelmänä käytettiin MTT:n Dremfia-sektorimallia, jossa on 18 tuotantoaluetta ja tarkka maatalouspolitiikan kuvaus, ja jossa muutostekijät voidaan ottaa huomioon (Lehtonen 2001). Malli sisältää pääasialliset maataloustuotteet ja niiden kysynnän. Malliin lisättiin eri kasvien hehtaarikohtaista tuottovaihtelua kuvaavat termit, jotta markkinahintojen ja satovaihtelun aiheuttama tuottovaihtelu voidaan sisällyttää tarkasteluun. Mallin aikajännettä venytettiin vuodesta 2020, johon asti lasketaan vuotuiset tuotannon, kysynnän, ulkomaankaupan ja panoskäytön kehitysurat, vuosiin 2030, 2040 ja 2050 pitkän aikavälin tasapainotiloina.

Perusura maataloussektorin kehitykselle laskettiin vuoteen 2050 asti nojautuen OECD:n julkaisemiin globaaleihin hintaennusteisiin 2009-2018 (OECD-FAO 2009). OECD:n julkaisemat reaalihintojen muutokset vuoteen 2018 asti pidettiin perusurassa muuttumattomina. Tässä tutkimuksessa arvioidut vaihtoehtourat maatalouden kehityksestä sisältävät erilaisia globaaleja hintasuhdeskenaarioita ja tuottavuusskenaarioita satotasoille Suomessa. Muiden ILMASOPU -hankkeen osioiden pohjalta muodostettiin kuusi tuottavuusskenaariota ja kirjallisuuden perusteella kuusi pitkän ajan markkinaskenaariota. Tuottavuusskenaarioiden pohjana olivat ILMASOPU -hankkeen arviot satopotentiaaleista, satoriskeistä äärevöityvissä sääoloissa, nykylajikkeiden rajoitteista, uusien 
lajikkeiden mahdollisuuksista sekä vaikeutuvasta tuholaistorjunnasta. Maatalouden kehitysura laskettiin yhteensä 36 eri skenaariossa.

OECD:n julkaisemat reaalihintojen muutokset vuoteen 2018 asti pidettiin perusurassa muuttumattomina

Markkinaskenaariot (6kpl):

Viljan hinta $+10 \%,+20 \%,+30 \%,+40 \%,+50 \%$ suhteessa perusuraan

Samalla lihan hinnannousuksi puolet viljan hinnannoususta

Maitotuotteiden hinnannousuksi neljännes viljan hinnannoususta

Tuottavuusskenaariot (6kpl):

Osittain muiden ILMASOPU -osioiden pohjalta muodostettiin seuraavat

$-40 \%,-20 \%, 0,+20 \%,+40 \%,+80 \%,+120 \%$

Tuottavuusskenaarioiden pohjana oli ILMASOPU-hankkeen arviot tuottavuuspotentiaalista, satoriskeistä äärevöityvät sääolot, nykyisten kasvilajikkeiden rajoitukset, Suomen olosuhteissa

DREMFIA-sektorimallilla laskettiin maatalouden kehitys eri markkina- ja tuottasuusskenaarioyhdistelmillä. Yhteensä laskettiin maatalouden kehitysura 36 skenaariossa. Tuottavuusskenaariot toteutettiin satotason kasvuna jokaiselle mallin 18 tuotantoalueelle lähtökohtana havaitut satotasot 1995-2009. Typen ja fosforin riittävyys varmistettiin käytetyissä satotasofunktioissa. Kasvaneen satotason aiheuttama viljan kuivauksen lisääntyminen hehtaaria kohti huomioitiin, siitä ei oletettu päästänä eroon vuoteen 2050 mennessä. Sen sijaan kasvinsuojelukustannusten nousua ei voitu tässä vaiheessa voitu ottaa huomioon. Toisaalta myöskään tilatason tuotannonjärjestelyjä kone- ja rakennuskantojen muutoksineen ja ajallisuuskustannuksen lieventymistä ilmastonmuutoksen seurauksena ei voitu ottaa huomioon. Kokonaisuutena tehtyjä arvioita voidaankin pitää maltillisina ja varovaisina.

\section{Tulokset}

Saatujen tulosten mukaan tuottavuuspotentiaalin nousu johtaa merkittäviin tuotannon ja maankäytön muutoksiin vain, jos keskimääräinen satotaso nousee merkittävästi (vähintään 40\%) tai jos markkinahinnat suhteessa panoshintoihin nousevat pysyvästi vähintään 20\%. Tuotannon kasvua hillitsee epävarmuuden kasvu. Satotason kasvu näyttäisi olevan tärkeä paitsi kasvintuotannolle, myös maidontuotannolle, jonka tuotanto kasvaisi pitkällä aikavälillä merkittävästi satotason kasvaessa. Jos satotaso nousee esimerkiksi 20\%, se johtaisi vilja-alan ja maidontuotannon kasvuun noin 15 prosentilla. Maataloustulo kasvaisi tällöin noin 15\% tuotannon uudelleenjärjestely- ja tehostumisetujen ansiosta. Tällaiset satotason nousun epäsuorat vaikutukset voivat olla jopa merkittävämpiä viljelijälle kuin pelkkä satotason kasvu entisellä tuotannonjärjestelyllä. Tämä tarkoittaa mm. sitä, että peltolohkojen pienen koon, hajanaisen sijainnin ja etäisyyden aiheuttamaa kustannushaittaa voidaan välttää keskittämällä tuotantoa lähellä oleville tai satoisimmille peltolohkoille. Lisäksi satotason kasvu mahdollistaa tuotannon alueellisen keskittämisen aiempaa enemmän, mikä tuottaa kustannussäästöjä paitsi maatiloille, myös koko elintarvikeketjulle. Kaikkia näitä ei kuitenkaan voida luotettavasti ennakoida tässä vaiheessa (esim. kasvinsuojelun muuttuminen 
voi edellyttää koko viljelykulttuurin ja viljelykiertojen muutosta), vaan toistaiseksi tyydyttiin varovaisiin arvioihin.

Suotuisimmissa skenaarioissa, joissa sekä satotaso että maataloustuotteiden reaalihinnat nousevat, viljantuotanto kasvaisi yli kaksinkertaiseksi ja maidontuotanto kasvaisi jopa 20-40\% 2040-2050 mennessä. Öljykasvien, syysviljojen ja herneen tuotanto siirtyisi suotuisimmissa tuottavuus- ja hintaskenaarioissa Etelä-Suomesta vähitellen kohti maan keskiosia. Öljykasveista tulisi osa kasvitilojen viljelykiertoa maan keskiosassa kuitenkin vasta lähempänä vuotta 2050 ja silloinkin sen pinta-alat jäisivät pieniksi vaikka tuotantomäärä lievästi kasvaisi. Syysviljojen viljely keskittyisi jatkossakin Etelä-Suomeen, jossa niiden satoisuus ja viljelyvarmuus kasvaisivat aiemmin kuin muualla. Viljan, myös leipäviljan, tuotantomäärät voivat kasvaa merkittävästi juuri Etelä-Suomen korkeampien satojen ansiosta. Rehuviljan tuotanto kasvaisi sekin ja myös maan keskiosissa.

Vielä kasvintuotantoakin suurempia hyötyjä voidaan saavuttaa kotieläintaloudessa. Korkeampi satotaso antaa mahdollisuuden keskittää viljely tuottavimmille peltolohkoille, mikä vähentää oleellisesti hajanaisen peltolohkorakenteen kustannushaittaa. Epäedullinen peltolohkorakenne rajoittaa erityisesti lypsykarjatuotantoa alueilla joilla peltomaasta on niukkuutta. Karkearehun tarve monine korjuukertoineen korostaa tilusrakennehaittaa, nostaa tuotantokustannuksia ja lisää laajentavan yrittäjän ennestäänkin suurta työmäärää. Suuremmat rehusadot pieneltä määrältä peltolohkoja parantaa olennaisesti mahdollisuuksia hyötyä suuren mittakaavan ja erikoistuneen tuotantomallin eduista. Korkeampi satotaso ja pidempi kasvukausi antaa mahdollisuuden kasvattaa eläinmäärää per hehtaari ja mahdollistaa suuremman rehusadon korjuun lähempää pienemmällä kone- ja ns. ajallisuuskustannuksella.

Ilmastonmuutoksen tuomat suuremmat rehusadot mahdollistavat korjuun aiempaa pienemmältä määrältä lohkoja, mikä samanaikaisen eläin-määrän kasvun kautta voi tuoda kotieläintalouteen kasvintuotantoa suhteellisesti suuremman tuottavuushyppäyksen. Näistä syistä satotason ja/tai maataloustuotteiden reaalihintojen nousu vahvistaisi lähivuosikymmeninä jo olemassa olevia alueellisia tuotantorakenteita. Merkittävä osa maataloustulon kasvusta tulisi pääomakannan ja peltoalan tehokkaammasta käytöstä, ja pienempi osa peltoviljelyn monipuolistumisesta tai korkeammista sadoista, mikä lisää myös hehtaarikustannuksia.

Suuria muutoksia alueellisissa tuotantorakenteissa ei tulosten mukaan kuitenkaan ole odotettavissa ennen vuosisadan puoltaväliä. Suotuisimmissa tuottavuusskenaarioissa maidontuotanto voi lisääntyä merkittävästi maan keskiosissa, jossa maata jäisi edelleen muuhunkin käyttöön. Viljely voi tällöin monipuolistua merkittävästi Suomen keskiosissa öljykasvien ja syysviljojen viljelyn myötä. Korkea rehusato ja kulutuskeskusten läheisyys pitäisi jatkossa maidontuotannon kannattavana ja laajenevana tuotannonalana myös Etelä-Suomessa. Näin käy vain jos nurmen satotasoa kyetään nostamaan, muuten tuotanto säilyisi entisellään vaikka viljan ja maidon hinnat nousisivat. Naudanlihantuotanto kasvaisi kasvavan maidontuotannon mukana, mutta kuitenkin hitaammin, sillä raskaiden sonnien kasvatus on huonosti kannattavaa, jos viljan hinta nousee. Sianlihantuotanto kärsisi korkeista viljan hinnoista, mikäli viljan hinta nostaa vain vähän sianlihan hintaa. Käytetyistä OECD-FAO 2009 hintaennusteista seuraa, että sianlihantuotanto vähenee kaikissa tarkastelluissa skenaarioissa. Sen sijaan siipikarjan tuotanto säilyisi hyvän kysynnän vuoksi lähes ennallaan.

\section{Johtopäätökset}

Ilmastonmuutos voi vaikuttaa Suomen maatalouteen tulosten mukaan enemmän globaalien hintasuhteiden muutosten kautta kuin kotimaisen tuottavuuspotentiaalin kautta. Nyt tehty tutkimus muodosti sisäisesti johdonmukaiset kehitysurat maatalouden alueellisesta kehityksestä suhteessa 
tuottavuus- ja markkinaskenaarioihin, joissa on kyse maataloustuotteiden hinnoista Suomen rajalla. Epävarmuuksien osalta tässä keskityttiin kasvituotteiden tuottovaihtelujen muutoksiin. Jos tarkasteluun olisi otettu systemaattisesti myös kotieläintuotteiden kasvava tuottovaihtelu, mm. maidontuotannon lisääntyminen olisi todennäköisesti jäänyt pienemmäksi.

Vaikka satopotentiaalin kasvu on MTT:n tutkimusten mukaan 1,5-3-kertainen vuosisadan aikana, ei ole itsestään selvää, parantaako ilmastonmuutos sittenkään Suomen maatalouden suhteellista asemaa markkinoilla. Esimerkiksi vähän tai edullisia energiapanoksia käyttävä maatalous monissa kehitysmaissa sekä mm. Brasiliassa, Australiassa, Uudessa Seelannissa ja Kaakkois-Euroopassa pystyy vastaamaan hintojen nousuun tehokkaammin ja kasvattamaan tuotantoa ilman tukia. Monissa kehitysmaissa on paljon mahdollisuuksia kasvattaa erityisesti kotieläintalouden tuottavuutta (matala lähtötaso). Satopotentiaali kasvaa myös muualla Pohjois-Euroopassa ja osissa Länsi-Eurooppaa jossa lähtötaso on selvästi Suomea korkeampi. Toisaalta hyvin harvoissa maissa on käytettävissä suhteellisesti yhtä paljon peltoalaa maataloustuotannon lisäämiseen kuin Suomessa, jossa on monin paikoin myös mahdollista raivata lisää peltoalaa.

On syytä muistaa, että ilmasto on vain yksi, joskin merkittävin, luonnonhaitta Suomen maataloudelle. Esimerkiksi peltolohkojen pienuus ja hajanaisuus sekä lyhyet kylvö- ja korjuuajat ovat merkittäviä kustannushaittoja. Samoin pienet tuotanto- ja kulutusmäärät ja pitkät kuljetusetäisyydet kotimaassa ja vientimarkkinoille ovat kilpailukykyhaitta joka ei ole poistumassa. Tuotantorakennusten rakentaminen on Suomessa jatkossakin kallista, koska siirtyminen pysyvästi leutotalviseen ilmastoon vie vuosikymmeniä. Sään yleistyvät ääri-ilmiöt rankkasateineen vaativat varautumista ja mm. peltojen peruskuivatuksen parantamista. Peltomaan niukkuus tuotantokeskittymissä ei sekään ole helposti ratkaistavissa, koska peltomaan raivaaminen aiheuttaa merkittäviä kasvihuonepäästöjä varsinkin turvemailla.

Suomen maatalous on tähän asti ollut suhteellisen tehoton maataloustuotteiden tuottaja. Maatalouden kustannukset ovat olleet 1,38-1,67-kertaiset markkinatuottoihin nähden 2000-2008. Merkittävä osa maataloustuesta on kulunut tuotantokustannuksiin, joita markkinatuotot eivät ole lähimainkaan kattaneet, eikä aina edes muuttuvia kustannuksia. Maataloustuotantoa rajoittavat jatkossakin ilmastosta riippumattomat luonnonhaitat ja riippuvuus yhteiskunnan tuesta. Maatalous on Suomessa vielä pitkään voimakkaasti politiikkavetoista. Tuotannon nopea kasvu markkinaehtoisesti ei ole todennäköistä tai edes mahdollista korkeiden kustannusten takia.

Ilmastonmuutoksen vaikutukset pellonkäyttöön alueittain riippuvat siis myös olemassa olevasta tuotantorakenteesta. Paitsi Suomi, myös yksittäiset alueet voivat erikoistua pellonkäytössä aiempaa vahvemmin suhteellisen etunsa mukaan. Läheskään kaikkia mahdollisia uusia viljelykasveja tai satoisampia lajikkeita entisistä ei siis tulla viljelemään kaikkialla missä se olisi mahdollista. Joitakin kasveja saatetaan viljellä ehkä vain pienellä osalla peltoalaa yksittäisillä alueilla. Huomattavakin tuotantomäärä voi keskittyä parhaille alueille ja peltolohkoille harvojen osaajien käsiin (tämä on jo toteutunut mm. sipulinviljelyssä). Jos kysyntä on joustamatonta (esim. peruna), satotason nousu alentaa tuottajahintaa ja viljelyalaa. Maataloustulo kasvaisi satotason kasvun seurauksena todennäköisesti suhteessa vähemmän kuin tuotantomäärä.

Jos tavoite on edelleen ylläpitää ja kehittää maataloustuotantoa Suomessa, keskeistä on epävarmuuksien ja huonojen vuosien sietäminen. Raskaat investoinnit ja kasvava satojen ja hintojen heilunta sopivat huonosti yhteen. Kasvinviljelyssä satovakuutusjärjestelmien tukeminen näyttäisi olevan sato- ja markkinaepävarmuuden kasvaessa yhä vaikuttavampi politiikkakeino (Lehtonen\&Kujala 2007). Kohdennettu satovakuutustuki kannustaisi kehittämään niiden kasvien ja 
tuotteiden tuotantoa jotka voivat saada suhteellista etua ilmastonmuutoksesta. Kaikissa tapauksissa, kuten öljykasvituotannossa, satovakuutustuki ei kuitenkaan olisi välttämättä riittävä kannustin lisätä tuotantoa korkean hintariskin takia.

Jos maataloutta kehitetään Suomessa sitkeästi ja pitkäjänteisesti - pahoistakin satovahingoista ja hintamyrskyistä selviytyen - edessä on paljon mahdollisuuksia. Satotason nousu mahdollistaa Suomessa aiempaa suuremmat mittakaavaetujen ja erikoistuneen osaamisen hyödyt. Kun otetaan huomioon muut luonnonhaitat, esim. hajanainen peltolohkorakenne, pitkät etäisyydet ja edelleen monia kilpailijamaita pienempi tilakoko, ilmastonmuutos voi tuoda Suomen maataloudelle suhteessa enemmän tuottavuuskasvua kuin muualla.

Koska maatalouden tuotteiden ja tuotantopanosten hintojen arvioidaan kasvavan, omavaraisuuden hyödyt kasvavat. Tämä koskee erityisesti valkuaisrehuja, joiden tuotannolle ilmaston lämpeneminen ja kasvukauden piteneminen antavat hyvät mahdollisuudet. Toisaalta soijan kysyntä maailmalla kasvaa ja tuotantoedellytykset heikkenevät sen päätuotantoalueilla pitkällä aikavälillä. Valkuaisrehun kysyntä saattaa kasvaa myös Suomessa, koska korkeamman satopotentiaalin hyödyt tehokkaamman tuotannonjärjestelyn kautta koskevat yhtä lailla kotieläin- ja kasvitilojakin.

Suomessa tuotannon tehostaminen ja joiltain osin myös kasvattaminen on mahdollista keskittämällä tuotantoa alueellisesti satojen parantuessa. Jotta positiivinen kehitys viljelymenetelmissä, -kierroissa ja kasvinsuojelussa pääsisi käyntiin, kasvinviljelyn monipuolistamiseen liittyviä riskejä viljelijöille tulisi alentaa ja kannustaa heitä koko arvoketjun kattavaan yhteistyöhön. Tulee kehittää tuotantoa, jolle on kysyntää.

\section{Kirjallisuus}

IPCC 2007. Summary for Policymakers. In: Climate Change 2007: The Physical Science Basis. Contribution of Working Group I to the Fourth Assessment Report of the Intergovernmental Panel on Climate Change. Solomon, S., D. Qin, M. Manning, Z. Chen, M. Marquis, K.B. Averyt, M. Tignor \& H.L. Miller (eds.). Cambridge University Press, Cambridge, United Kingdom and New York, NY, USA, $18 \mathrm{p}$.

Jylhä, K., Tuomenvirta, H. \& Ruosteenoja, K. 2004. Climate change projections for Finland during the 21st century. Boreal Environment Research 9: 127-152.

Lehtonen, H. 2001. Principles, structure and application of dynamic regional sector model of Finnish agriculture. Academic dissertation. Systems Analysis Laboratory, Helsinki University of Technology. Publisher: Agrifood Research Finland, Economic Research (MTTL). Publications 98. Helsinki. 265 pages. http://lib.tkk.fi/Diss/2001/isbn9512256894/

Lehtonen, H. \& Kujala, S. 2007. Climate change impacts on crop risks and agricultural production in Finland. Paper presented in 101st EAAE seminar "Managing Climate Risks in Agriculture", held in Berlin, Germany, July 5-6 2007. 21 p.

http://ageconsearch.umn.edu/bitstream/9259/1/sp07le01.pdf

Peltonen-Sainio, P., Jauhiainen, L., Hakala, K. \& Ojanen, H. 2009. Climate change and prolongation of growing season: changes in regional potential for field crop production in Finland. Forthcoming in Agricultural and Food Science.

OECD 2009. OECD-FAO Agricultural Outlook 2009-2018. Available at www.oecd.org 